\title{
Supply and Demand of Fake News: Review and Implications for Business Research
}

\author{
Zlatinka N. Blaber \\ Salem State University \\ Linda Jane Coleman \\ Salem State University \\ Saverio Manago \\ Salem State University \\ Kathleen Hess \\ Salem State University
}

'Fake news' aims to shake society's understanding of what the truth is and cast doubts on whether the truth even matters, threatening to erode democracy and destroy the fabric of society and business. This paper investigates this phenomenon and positions it in the broader business research context by reviewing the fake news literature from a variety of disciplines; proposing suggestions for future business research on the supply and demand of fake news; and raising the awareness of what fake news is, how dangerous it can be, how easily it can go viral, and how it can be curtailed or managed.

Keywords: Fake News, Communications, Information, Supply and Demand, User generated.

\section{INTRODUCTION}

In the current information-rich society, it is difficult to sort through the daily information overload and determine what is true and what is not. A new communications ecosystem is in the making and it affects not just individuals, but also businesses. How can individuals discern genuine news among all the information they come across on their smart phones, tablets, or computers? From an individual perspective, which traditional broadcast news channels, radio stations, and social media outlets are to be trusted and which ones are to be distrusted? What messages aim to maliciously shape public opinion or censor information rather than clarify truth from fiction? From a business perspective, can fake news about products or services decrease purchase likelihood and therefore negatively impact downstream revenues (Berger, Sorensen, \& Rasmussen, 2010)? What about consumer acquisition and retention, brand equity, and company reputation? Can negative user-generated product online content adversely affect consumers during the stages of the marketing funnel - awareness, consideration, purchase intent, and 
satisfaction (Colicev, Kumar, \& O'Connor, 2018)? While the questions are many, the answers are not so clear-cut. "With distrust of the news media at an all-time high, a skeptical public looks to alternative information sources and becomes easier to bamboozle. It's in this space, devoid of principles," where fake news flourishes (Attkisson, 2017, p. 3). Dwindling citizen confidence in existing institutions undermines the credibility of traditional news channels and predisposes the public to open itself to alternative sources of information (Bennett \& Livingston, 2018), some of which are questionable and misleading.

Companies' control over messages in today's inter-connected world is becoming more and more limited since consumers themselves can also disseminate messages about companies' products and services. This is easily done via social media platforms (Mangold \& Faulds, 2009), such as Twitter, Facebook, and SnapChat. The spread of information brings challenges to companies and brands that wish to be featured positively on social media and to be perceived favorably in the consumers' mind (Poddar, Banerjee, \& Sridhar, 2019; Warner-Søderholm et al., 2018). 'Paid' and 'owned' media (e.g., advertising and companies' websites, respectively) are now faced with traditional 'earned' (e.g., publicity and press mentions) and social 'earned' media (e.g., blogs and social media) (Stephen \& Galak, 2012). If earned media messages are accompanied by unjustified or justified negative user sentiments or comments with regard to products and services, companies may see a threat or an opportunity to improve, respectively. The marketing and consumer behavior literatures are replete with scholarly efforts aimed at better understanding social earned media's negative impact on business (e.g., Hsu \& Lawrence, 2016; Montgomery \& Gray, 2017). Consumers' decision to contribute online reviews and ratings of products and services has also been scrutinized in the extant literature (Moe \& Schweidel, 2012). Such reviews and ratings may or may not be genuine, however. Product misinformation may be generated and spread either inadvertently or purposefully.

This article focuses on a topic that has received relatively little coverage in the business literature: the intentional creation and dissemination of misinformation through social media disguised as real news, i.e. fake news. Scholarly efforts have mostly focused on rumor transmission and re-transmission (not necessarily intentional spreading of fake news), on online word-of-mouth (Gruen, Osmonbekov, \& Czaplewski, 2006; Hennig-Thurau, Gwinner, Walsh, \& Gremler, 2004; Relling, Schnittka, Sattler, \& Johnen, 2016; Trusov, Bucklin, \& Pauwels, 2009), on Facebook use intention (Wu, 2015), on social media product failure firestorms (Hansen, Kupfer, \& Hennig-Thuran, 2018), on the 'perverse halo' or negative 'spillover effects' of product recall news on social media (Borah \& Tellis, 2016), and on favorable or unfavorable virality (Akpinar \& Berger, 2017). Yet, fake news per se remains largely understudied in the business literature.

This paper investigates the recently-coined fake news phenomenon and positions it in the broader business research context, mostly that of marketing and consumer behavior. First, the manuscript aims to provide a succinct but informative review of the fake news literature from a variety of social science, political science, communications, and business disciplines. Second, it proposes suggestions for future empirical and theoretical business research on the supply of and demand for fake news. Given the great political, societal, and economic implications of fake news, this paper also aims to heighten the awareness of business academia and the business community of what fake news is, how dangerous it can be, how easily it can go viral, and how it can be curtailed or managed.

The manuscript is structured as follows: first, the definition of 'fake news' used in this article is specified; second, the history of fake news is summarized; third, fake news' supply, demand, and the platforms facilitating its proliferation are discussed; forth, the authentication and management of fake news are presented; sixth, fake news' place in the business literature is scrutinized by looking at research questions from prior studies and by delineating implications for future research on the demand and supply of fake news; and finally, a short discussion and conclusion follow.

\section{FAKE NEWS: DEFINITION AND HISTORY}

Mark Twain has often been attributed with the saying "A lie can travel halfway around the world while the truth is putting on its shoes," a fact that is even more pertinent in today's technology-abundant 
world than in Mark Twain's nineteenth and early twentieth centuries. One disturbing consequence of this mismatched race between truth and lies is that people may be led to impulsively believe emotion-laden false statements. Later, they may refuse to believe the objective reality when, or if at all, the reality crosses their news feed. The term 'post-truth,' first used by Steve Tesich in The Nation (Tesich, 1992) and word of the year in 2016 by the Oxford English Dictionary (Berthon \& Pitt, 2018), partially explains this mismatch phenomenon. This term means believing information based on not very factual, but emotional appeals instead of believing the objective facts. In sum, partially due to recent, fast developments in technology and connectivity, facts and evidence are ceding their way to less factual opinions, personal beliefs, personal values, and emotions that easily proliferate via online chatter (Rochlin, 2017). The affective threatens to take over the cognitive.

Recently, fake news has been the topic of a wide variety of disciplines: political science (Allcott \& Gentzkow, 2017; Balmas, 2014; Belhadjali, Whaley, \& Abbasi, 2017; Dimitrova \& Matthes, 2018; Lance \& Livingston, 2018; Persily, 2017), journalism and communications (Brummette, Marcia, Michail, \& Messner, 2018; Wasserman, 2017), cognition (Lewandowsky, Ecker, \& Cook, 2017; Pennycook \& Rand, 2019), public relations (Krishna, 2017), economics (Kshetri \& Voas, 2017), health policy (Waszak, Kasprzycka-Waszak, \& Kubanek, 2018), library science (Anderson, 2017; Batchelor, 2017; Rochlin, 2017; Lor, 2018), legal studies (Burshtein, 2017; Klein \& Wueller, 2017; Napoli, 2018), intelligence (Serra \& Sardar, 2017), transportation (Love \& Ahiaga-Dagbui, 2018), defense (Downes, 2018), and information studies (Ciampaglia, Mantzarlis, Maus, \& Menczer, 2018; Prier, 2017). To our knowledge, the business literature has produced very few studies dedicated to or touching on the fake news phenomenon (e.g., Berthon and Pitt, 2018; Brigida and Pratt, 2017; Wu, 2015). It is our hope that fake news will be curtailed, if not fully ousted from our social reality very soon. Until then, it merits the attention of business scholars in the light of its potentially negative impact on society, democracy, and business.

\section{Definition}

What is fake news? First, common opinion holds that fake news is inaccurate, biased information created and disseminated with the intent to deceive (Brummette et al., 2018; Currie, 2018; Shin, Jian, Driscoll, \& Bar, 2018). Second, fake news is presented as legitimate news, not just as an honest opinion, for political or financial gain, usually on social media (Rochlin, 2017). The definition used in this paper meets the two requirements just mentioned. Other terms similar in meaning to 'fake news' are: hoax, rumor (a broader term, i.e. unconfirmed claims) (Chua \& Banerjee, 2018; Chua, Tee, Pang, \& Lim, 2017), deception, misinformation (another broader term, i.e. intentionally or unintentionally false), disinformation (European Commission, 2018), information disorders (Wardle \& Derakhshan, 2018), alternative facts, and alternative truth. Online fake news has also been referred to as digital deceit (Ghosh $\&$ Scott, 2018) and digital misinformation (An et al., 2017). Political propaganda may sometimes meet the definition criteria of fake news although generally it is not labeled as such by most observers (Currie, 2018).

Attkisson (2017), a journalist, calls certain types of fake news 'smears.' Smears become so much embedded in our everyday lives that "we barely flinch at the most audacious claims" (p. 3). She also posits that the determination of whether something is a smear would be different depending on whom one asks: "One man's smear is another man's truth" (Ibid.). Generally, a smear is "an effort to manipulate opinion by promulgating an overblown, scandalous, and damaging narrative" (Ibid.). The author explains that often a smear's goal is to destroy certain ideas by first ruining the people that are the most effective at communicating them. As an investigative journalist, Attkisson has experienced being smeared herself. Usually, a smear is "inherently interesting and, preferably, salacious...explainable in a sentence or two" and it "must confirm what a lot of people want to believe... Repeat it often enough and it becomes undeniable - something "everyone knows." (p. 4).

Again, from a journalism perspective, if a reporter receives a leak (always private and often anonymous), as opposed to a press release which is available to everyone: 
...it is like having an exclusive. If she can get this information out quickly, she will scoop all her competitors. The problem is, some people who offer up leaks or exclusives may be lying. They may be gambling that a reporter is more interested in a scoop than in accuracy ...Reputable reporters will not take leaks at face value. They will know that they may be being manipulated by their source... Unfortunately, deadline pressure makes such responsible journalism harder to do. There are always news outlets willing to publish first and ask questions later. Sadly, this has led to a race to the bottom, in which disreputable news outlets get the clicks and make the money, while those that are responsible and perform due diligence lose out (Bartlett, 2017, p. 18-19).

Thus, another possible definition of fake news is irresponsible journalism, a race to be first to report on an interesting issue people care about. Attkisson (2017) would agree with Bartlett above. She further writes that reporting without fact-checking may be advancing an agenda: "Sometimes fake news is picked up and reported seriously in the domain of once-respected straight news outlets. The news organizations may be guilty of not checking facts carefully enough. They could be in a rush to beat the competition. Or they could be advancing an agenda" (p. 254). What would be better - an honest mistake by a respectable news source or a piece of fake news from an off-brand online website? Coming back to the issue of intention, the latter is deliberate, while the former is not. Attkisson (2017) argues that "mistakes at 'real" news organizations are more harmful because more readers are likely to believe them than off-brand online sites" (p. 252).

As this implies, not all fake news is equally bad. Johnson and Gluck (2016) distinguish among five categories of false stories: 1) entirely false ones, 2) slanted or biased false ones, 3) pure propaganda, 4) stories that misinterpret or misuse data, and 5) sloppy, imprecise news reporting. It is also important to note that the term fake news has been qualified as incomplete and misleading because information labeled as such is not always entirely fake and it is sometimes not actually news (Bârgăoanu \& Radu, 2018).

\section{History}

The term 'fake news' has not always carried the negative connotations that it holds today. One of the term's earliest encounters in the academic literature is in Borden and Tew (2007) where the US comedy TV shows The Daily Show with Jon Stewart and The Colbert Report with Stephen Colbert are analyzed from a virtue theory perspective. In a similar vein, even though NBC's Saturday Night Live has become one of the most widely known fake news programs in the US, it does not fall within the definition of fake news since it is devoid of malicious intent to deceive. The news is presented however (satirically) as real news. Saturday Night Live is entertaining and unthreatening instead, with comic personalities and topical jokes (Amarasingham, 2011; Day \& Thompson, 2012; Nelson \& Taneja, 2017). Political parody via false news is not just a US phenomenon. It has also been recently examined in the scholarly literature from the Serbian context (Petrović, 2015).

The current, more negative, definition of 'fake news' did not enter the public discourse until 2016 around the U.S. presidential elections. Attkisson traces the 'public ignition' of the fake news movement to 16 September 2016 - to a group named First Draft that created a network of partner organizations to tackle ill-intended hoaxes and fabricated news reports. This is not to say that deception had not been used as a persuasion tactic before this time; in fact, the use of 'fake news' has been in existence for much longer. Young (2017) provides a plethora of historical and current examples involving forgery, hoaxes, and other types of fakery dating back to the 1800's when P.T. Barnum introduced the world to his 'curiosities,' such as the Fiji mermaid. Throughout history, one of the common factors that makes old fashioned 'curiosities' and current day fake news effective vehicles for swaying a person's thoughts and behaviors is the emphasis on emotion and affect rather than rational thought - a practice for which Stephen Colbert coined the term 'truthiness' in 2015 (Berthon \& Pitt, 2018). These authors define 'truthiness' as perceiving the validity of something based on how this thing feels. Borden and Tew (2007, p. 304) further define the word as an "instinctive knowing unencumbered by logic or facts." Back in the 1800 's, people may have been fooled into going to see the curiosities, but they left the show with the 
realization that they had been fooled. Now, thanks to new technologies and non-prohibitive costs, fake news reports are being published in ever-more sophisticated and convincing ways.

\section{FAKE NEWS: SUPPLY, DEMAND, AND PLATFORMS}

Like all communication, fake news requires both a sender and a receiver. For the purposes of this paper, the sender is the supply side and the receiver is the demand side of fake news.

\section{Supply}

'Supply' of fake news consists of: 1) the creation of fake news by individuals who have malicious intent toward someone or something (usually in the political sense) and/or individuals who aim to derive personal financial benefit from clickbait (e.g., online advertising revenue) linked to content that goes viral and 2) the re-transmission of fake news (e.g., social media sharing) by people who are either aware or unaware of the falsehood of the messages they pass along to others. Public outrage against fake news is mostly targeted at the supply side, i.e. at the creators and distributors of disinformation ("Fake News Flourishes," 2018). Suppliers of fake news are not all members of the liberal left or the conservative right. Both sides have been spotted generating fake news about the other side in extreme, partisan ways (Attkisson, 2017). Fake news 'double agents' also exist, to complicate matters even further. According to Attkisson, such double agents would have no qualms "generating fake news about themselves to justify the movement to crack down on supposedly fake news" (p. 250).

Among the famous, and very consequential, examples of fake news' supply include the Pizzagate scandal that negatively implicated Hillary Clinton's 2016 presidential campaign (Harris, 2018), the involvement of youth from the small town of Veles, Macedonia in spreading fake news about Mrs. Clinton just before the 2016 presidential elections, an act that brought them virality and therefore significant clickbait income (Allcott \& Gentzkow, 2017), and the WTOE5News.com fake news report seen and believed by many Americans just before the 2016 presidential elections claiming that Pope Francis had officially endorsed Donald Trump for President (as head of the Catholic Church, the Pope does not endorse political figures) (Fernandez, 2017). All these examples are from the political front. Business illustrations of the supply of fake news are reserved for future sections. The re-transmission of fake news stories can happen very fast on social media, with or without the awareness of those sharing that the news is 'fake.' A further section discusses the platforms and technologies that make such sharing possible.

\section{Demand}

'Demand' for fake news refers to the exposure of individuals to fake news by either hearing or reading a story or seeing online images or videos whose creators have knowingly distorted the truth and made the presentation seem legitimate. Often but not always, the demand side of fake news pre-supposes social media exposure. Research has found that those users with high online availability are more susceptible to consuming fake news than those who are not as available online (Nelson \& Taneja, 2017). "[S]ocial network sites play an outsized role in generating traffic to fake news," as well (p. 1). People tend to pay more attention to information that is in line with their preferred outcome (Tanner \& Carlson, 2009) and tend to perceive that false news has a greater effect on 'others' than on themselves (Jang \& Kim, 2018).

The theory of homophily may be useful to help understand the demand side of fake news. This theory proposes that social media users have the propensity to communicate with and befriend other users with similar characteristics and ideologies to their own (Brummette et al., 2018). This inclination to interact with people who are just like oneself creates so-called 'echo-chambers' or spaces on the Web that reflect the same opinions and values amidst homogeneous social networks (Garrett, 2009; Himelboim, Smith, \& Shneiderman, 2013; Himelboim et al., 2016). The latter work demonstrates that online networks' members that are characterized by high levels of homophily display similar traits and beliefs and tend to communicate in similar ways as far as tone and valence are concerned. Fake news "no longer means 
factless or slanderous news, but rather news that is seen to attack a person's pre-existing beliefs" (Rochlin, 2017, p. 386). From a theoretical perspective, Mihailidis and Viotty (2017) revisit the work of critical theorist Guy Debord and argue that the spread of 'citizen-driven spectacle' is "a direct result of an increasingly polarized and distrustful public spending an increasing amount of time in homophilous networks where contrarian views are few and far between" (p. 441). Utilizing the theoretical concept of 'spreadable media,' these authors explore how online citizen expression nurtured the media spectacle surrounding the 2016 US presidential elections.

One of the factors that help explain why low-quality information often becomes much more viral than high-quality information is that online social networks are structurally segregated and polarized (An et al., 2017; Ciampaglia et al., 2018). The 'echo-chambers' that result are exacerbated by algorithms that personalize online experiences and hinder exposure to ideologically-diverse sources of information (Ciampaglia et al., 2018; Nikolov, Oliveira, Flammini, \& Manczer, 2015). 'Filter bubbles' refer to the assumption that the personalization algorithm predicts what information social network users will find of interest, a fact that creates virtual isolation from diverse opinions (Pariser, 2011; Seargeant \& Tagg, 2019). Other factors that also contribute to the virality of low-quality, often fake, news are limited attention (Weng, Flammini, Vespignani, \& Menczer, 2012), social bot manipulation (Ferrara, Varol, Davis, Menczer, \& Flammini, 2016), and popularity bias (Nematzadeh, Ciampaglia, Menczer, \& Flammini, 2017).

The links between ideological polarization and fake news have been explored during the period of the Brexit referendum in the United Kingdom (Spohr, 2017). Spohr provides evidence for the co-existence of two social media echo-chambers at the time. Users of social media either focused on the pro-Brexit or the anti-Brexit stance without paying much attention to the opposite side. Two variables are believed to influence the users' attachment to one or the other echo-chamber - the distance between the sentiment of the story and the emotional response of the users consuming the content.

Algorithmic personalization has led to people's actions being increasingly shaped by technological developments which people do not fully understand, a fact that has an adverse impact on democracy ${ }^{1}$ and the democratic debate (Jones \& Hafner, 2015).

What is more, [governments] are unlikely to do much to stem the flow of disinformation so long as there remains an audience of readers hungry for fakery...Supply-side solutions to the problem of fake news are not hopeless. The media business remains concentrated. Better behavior by the giants, from Facebook to Fox, could limit the spread of untruths. But well-intentioned media organizations can only do so much, as long as a population is ideologically divided and hungry for bias and misinformation ("Fake News Flourishes," 2018).

\section{Platforms}

Platforms and new technological tricks facilitating the spread of fake news online include search engines, social media, bots, trolls, digital manipulation with Photoshop and phone apps, voice dubbing technologies and algorithms. For example, a basic search on Google brings up that Nestle is evil, that Volkswagen is going out of business, that Apple is dead, that Europe is lost, and that America is doomed (Berthon \& Pitt, 2018). By their very nature, online platforms contribute to the proliferation of disinformation. Just like the suppliers of fake news, these platforms have also been the object of public criticism - Facebook's algorithms that foster homophily and the company's dealings with the English Cambridge Analytica are just two recent examples. It is increasingly difficult to differentiate between fake and true news thanks to the relative ease of use of technological tricks. Spreadborough and Software (2017, pp. 11-12) rightfully note: 
It is easy to see how even minor changes can tell an entirely different story. For example, a quick rearrangement of words and letters on a document can change dates, statements and price quantities. Or the addition of just one face into a crowd scene creates an alibi out of thin air...Seeing is no longer believing...To effectively carry out fraud investigations in a world where anyone can edit and manipulate a photo at the touch of an app, we must remain vigilant and treat photo images with a pinch of salt.

By the 1990s, news organizations had already started to exploit new web-enabled technologies, such as email, blogs, online videos, and Internet sites to reach larger audiences and users had already started to turn to online sources of information for their news needs. Given that access to traditional news channels is usually on a subscription basis and given that access to online news venues may be free of charge, an increasing number of people nowadays gets their information primarily online.

Trolling was started by anonymous users who posted insensitive comments on blogs. These users would leave deliberately rude comments "that served no purpose other than to hurt, shock, offend and sow discord. The protection of anonymity offered the benefit of unaccountability" (Hannan, 2018, p. 220). Bastos and Mercea (2017) have studied about 10 million tweets related to the Brexit referendum in the United Kingdom and found a network of Twitter bots of more than 13,000 accounts. Bots are computer scripts that imitate human activity on Internet platforms. Trolls and bots have been linked in the literature to authoritarian regimes, among others. According to Bennett and Livingston, in China, the Wumao Dang or the 50 Cent Party consists of over two million people who are paid to post comments on social media. Similarly, in Russia, the 'St. Petersburg Troll Factory' is a company under the official name of Internet Research Agency that also trains people in trolling and pays them for it (Bennett \& Livingston, 2018). The same source points out that in 2013 alone the Troll Factory had about 600 employees and an estimated annual budget of US\$10 million. These trolls were instructed to post carefully-crafted news articles fifty times per day. Other trolls were instructed to maintain a certain number of Facebook and Twitter accounts and publish fake news several times daily. Trolls have created fear among people and have limited freedom of speech; thus, they should be considered as a serious risk to national security (Aro, 2016). The US special prosecutor, Robert Mueller, is currently investigating matters of national security related to Russian trolls and has indicted twelve Russian agents for hacking the Democratic National Committee and the Clinton presidential campaign just prior to the 2016 election.

\section{FAKE NEWS: AUTHENTICATION AND MANAGEMENT}

Busy news consumers cannot be expected to research and verify every single message they are in contact with on the news or social media; this is the journalist's job (Bartlett, 2017, p. 16). Even so, authenticating fake news and managing its proliferation are strongly recommended. For instance, one may pay attention to terminology that would lead one to either trust or mistrust a fact or a piece of evidence used to justify a conclusion.

\section{Authentication}

It is not always easy to immediately spot fake news; however, some good advice has been shared by Harris (2018): when confronted with a piece of news that one suspects to be bogus, one should look to see whether the author has provided their credentials. Johnson and Gluck (2016) suggest that one checks on whether the author is a real expert or a self-proclaimed one. Another good piece of advice is to perform a web search to find out whether the author has written any other articles. One needs to be careful in such articles' absence. According to Harris, trustworthy articles usually provide sources for facts and figures. Given word limitations on journalistic pieces of work (Bartlett, 2017) however, sources are sometimes omitted. Readers or viewers should be skeptical of articles that offer un-backed by a legitimate source data. Checking the domain name of the website hosting the article is also recommended. Poor writing skills are another good tip-off for fake news: real news websites are prepared by professional writers who use the help of editors. To better spot fake news, one can also refer to fact-checking websites, such as 
Snopes.com, FactCheck.org and PolitiFact, although these websites are not to be fully trusted. ${ }^{2}$ Before sharing a piece of news on social media, Harris recommends investigating the story using other sources of information. Doing "some basic detective work" (p. 41) would help decide to what degree the story may be true. Johnson and Gluck (2016) suggests that one google the headline that he or she suspects of falsehood with the word 'false' after it. If the story is not true, corroborative information may be found online.

Bartlett (2017) advises that news users check on whether the reporting is based on the account of someone with direct, personal knowledge of what happened (e.g., was the reporter there when a political figure made a certain statement?), rather than on simple hearsay. Not all primary sources, e.g., eye witnesses, should be taken at face value: "people lie, or they misremember, or they have some ax to grind that causes them to shade the truth in some way - by, for example, leaving out some critical piece of information in otherwise truthful statements" (p. 14). This is the reason why on crime shows, such as CSI, investigators do not necessarily rely on eye witness accounts of events, claims Bartlett. Instead, investigators mainly rely on the forensic evidence gathered from crime scenes. The same logic applies to journalism, continues the author: documentary evidence is to be much preferred over unreliable eye witness narratives. Examples of documentary evidence include DNA evidence, contracts, and tax returns, among others. Further, Bartlett elaborates on the veracity of testimony and documentary evidence:

Evaluating the veracity of either testimony or documentary evidence may depend on how close it is to the event in question. A statement or document produced shortly after an event occurs is likely to be more reliable than, say, a memoir produced many years later, although it may still be preferred to a secondary source. Thus, one would probably place more weight on a diary entry or a memo written immediately after an important meeting than a published memoir that may be self-serving or based on selective memory. (p. 15)

The American Institute of Certified Public Accountants' (AICPA) National CPA Financial Literacy Commission has offered advice to help consumers identify instances of fake news: consumers need to make sure the news comes from legitimate sources, not from a 'spoofed' or 'counterfeit' website that looks legitimate but is used to sell products. The Commission reminds consumers that most investment plans are designed for the long term. A breaking stock market news may be a hoax and one should avoid acting on impulse on such news. If a consumer has an urgent financial question, he or she is advised to ask the Money Doctors, qualified CPAs who also hold the Personal Financial Specialist (PFS) designation ("Fake financial news," 2017).

\section{Management}

Many information-providing sources are examining ways to support journalism and decrease the occurrence of fake news. For example, YouTube (owned by Google) is taking active measures to reduce misinformation and support more 'authoritative' news organizations (Ortutay, 2018). Fake news may originate on websites and social media, such as YouTube, Facebook, and Twitter can be used to re-direct people to the websites where the fake news was originally posted (Currie, 2018). Social media distributes enormous amounts of news stories every second. Long gone are the days of social media being limited to sharing activities and events of one's personal life. It was only a matter of time before this medium got exploited (Fulgoni \& Lipsman, 2017) by fake news creators.

Responding to the intense, negative outcry regarding fake news, many organizations that do online advertising have updated their policies to not allow services to publishers of fake news. For two months in 2016, Google banned 200 AdSense publishers for possible violations of misrepresentative content (Klein \& Wueller, 2017). An inexpensive and accessible electronic medium, social media allow for information sharing, development of relationships, and the discovering of commonalities among users (Jue, Marr, \& Kassotakis, 2010). Companies, especially platform providers, around the world have taken steps to stop the spread of fake news. Facebook, whose reputation has been tarnished lately for failing to 
stop the spread of fake news on its platform, has taken a stand against fake news by partnering with factchecking organizations (Harris, 2018).

Digital technology often brings about changes that turn out to be disruptive or result in perverse effects (e.g., fake news and other online falsehoods). That's why it needs to be politically regulated under a sound governance framework (Hynes, 2017). To address the problem of fake news, Tsipursky and Morford (2018) propose an intervention, the Pro-Truth Pledge, which draws on behavioral research and the environmental movement. Those who sign the pledge agree to abide by twelve rules: verify, balance, cite, clarify, acknowledge, re-evaluate, defend, align, fix, educate, defer, and celebrate. Debunking fake news is another way of managing it (Lewandowsky, Ecker, Seifert, Schwarz, \& Cook, 2012). Because fake news can lead to sub-optimal decisions about consequential matters and because it is persistent and hard to correct, debunking it is an important endeavor (Chan, Jones, Jamieson, \& Albarracín, 2017, p. 1531).

\section{FAKE NEWS IN THE BUSINESS LITERATURE}

Reviewed above was the literature on fake news from a variety of disciplines - e.g., communications, journalism, political studies. The sections below focus on the business literature. Suggestions for future business research on fake news are also provided.

\section{Research Questions from Prior Literature}

Table 1 presents selected research questions (RQs) from the extant literature on fake news and classifies them into two categories: 1) RQs related to the supply side of fake news, i.e. the production and re-transmission of fake news and 2) RQs related to the demand side of fake news, i.e. its consumption.

TABLE 1

RESEARCH QUESTIONS ON FAKE NEWS FROM PRIOR LITERATURE

\begin{tabular}{|c|c|c|}
\hline & Research Questions (RQs) & Sources \\
\hline Supply of fake news & $\begin{array}{l}\text { "How do source credibility and message } \\
\text { plausibility correlate with retransmission?" } \\
\text { "How does message type correlate with } \\
\text { retransmission?" } \\
\text { "How does message type moderate the } \\
\text { relationships between source credibility and } \\
\text { retransmission, as well as message plausibility } \\
\text { and retransmission?" } \\
\text { "RQ1. Who are the predominant root sources of } \\
\text { fake news and real news? } \\
\text { RQ2. How do the evolution trees differ between } \\
\text { fake and real news in terms of tree } \\
\text { characteristics (i.e., breadth, depth, and } \\
\text { degree)? RQ3. How do evolution trees differ } \\
\text { between fake news favoring Donald Trump and } \\
\text { Hillary Clinton in terms of tree characteristics } \\
\text { (i.e., breadth, depth, and degree)?" }\end{array}$ & $\begin{array}{l}\text { Chua et al. }(2017, \mathrm{p} . \\
708) \\
\text { Jang et al. }(2018, \text { p. } 105)\end{array}$ \\
\hline
\end{tabular}




\begin{tabular}{|c|c|c|}
\hline & $\begin{array}{l}\text { "Do political rumors recur?...Is there any } \\
\text { difference in the diffusion patterns between true } \\
\text { and false rumors?"... Do comeback rumors } \\
\text { show content changes between peaks?"...Do } \\
\text { persistent rumors depend on external sources } \\
\text { that keep refreshing the rumor?" } \\
\text { "Will the network issue agenda of fake news } \\
\text { predict the overall news media's agenda } \\
\text { online?...Will the network issue agenda of fake } \\
\text { news predict other, nonpartisan media's } \\
\text { agenda?" }\end{array}$ & $\begin{array}{l}\text { Vargo, Guo, and } \\
\text { Amazeen (2017, pp. } \\
\text { 2031-2033) }\end{array}$ \\
\hline Demand for fake news & $\begin{array}{l}\text { "How is the term "fake news" discussed on } \\
\text { Twitter and what role does politics play in those } \\
\text { discussions?...What are the prevalent } \\
\text { discussions surrounding the "fake news" term } \\
\text { (most frequent words used, most common } \\
\text { hashtags, and users most often replied } \\
\text { to)?...What are the characteristics (type of user, } \\
\text { gender, and political affiliation) of Twitter users } \\
\text { who comprise the online communities that form } \\
\text { around the discussions of "fake news"?" } \\
\text { "Are tweets about "fake news" disseminated in } \\
\text { the primary Twitter networks similar in regard } \\
\text { to political ideology, context and valence?" } \\
\text { "Are Romanians trusting religious and } \\
\text { security/public order institutions more than } \\
\text { political institutions and the legacy media?" } \\
\text { "Are Romanians using more the legacy media } \\
\text { outlets than the online media for reading news?" } \\
\text { "Are Romanians using more than the average } \\
\text { European citizen Internet platforms for reading } \\
\text { news?" } \\
\text { "Are Romanians less aware of the fake } \\
\text { news/fake stories phenomenon than the average } \\
\text { European citizen?" } \\
\text { "Is Romanians' digital behaviour riskier than } \\
\text { the behaviour observed at the average European } \\
\text { citizen?" } \\
\text { "What is the size and level of engagement of the } \\
\text { fake news audience compared with the real } \\
\text { news audience?" } \\
\text { "How does the overall online usage of the fake } \\
\text { news audience differ from the real news } \\
\text { audience?" }\end{array}$ & $\begin{array}{l}\text { Nelson and Taneja } \\
(2017, \text { p. 5) }\end{array}$ \\
\hline
\end{tabular}




\section{Implications for Future Research}

Future Research on Supply

Future research in business can examine characteristics of fake news messages, such as 'source credibility' (experience and connectivity to other social media users) and 'message plausibility' (mediumspecific features such as hash tags, image, mention and emotions) (Chua et al., 2017) to increase understanding of the supply-side of fake news. Chua and colleagues focus on rumor messages (not necessarily fake news messages) on Twitter surrounding the alleged death of the Father of Singapore, Mr. Lee Kuan Yew, prior to his actual death and find that source credibility and message plausibility are positively related to rumor re-tweeting. Rumor messages - which, when incorrect, may be honest mistakes - may be quite different from fake news which is intentionally false. It would be a worthwhile effort to find out whether Chua and colleagues' findings on rumor messages also extend to fake business news messages and to what extent. Researchers could also expand the empirical context to other platform providers besides Twitter. Certain platform users are known to have a higher network connectivity on social media than others. For example, influential individuals have traditionally been able to influence the opinions of the masses (Katz \& Lazarsfeld, 1955) by having numerous followers. Yet, in today's world of social media, ordinary users are also capable of influencing a lot of people (Rogers, 2003). Future studies are encouraged to explore the re-transmission frequency and other characteristics of fake business news messages by highly influential social media users versus this of ordinary users.

Following Jang et al.'s (2018) methodology, future research may benefit from recent developments in computational networks, more specifically evolution tree analysis. Jang and colleagues examine the 2016 US presidential election by computationally retrieving hundreds of thousands of tweets about thirty fake and thirty real news stories. The stories' contents, producers, sources, and evolution patterns are then examined. The study finds that tweets about fake news come mostly from ordinary users; however, these tweets often include links to questionable news sites. Real and fake news stories are found to differ in terms of evolution patterns: the results "indicated that tweets about real news spread widely and quickly, but tweets about fake news underwent a greater number of modifications in content over the spreading process" (p. 103). Even though ill intent is difficult to prove to qualify the news as 'fake,' future business studies may try to utilize evolution tree analysis of fake news about products, services, and business entities in general - the news' contents, producers, sources, and evolution patterns - by applying Jang and colleagues' approach and methods.

Shin et al. (2018) may be enlightening to researchers interested in exploring the recurrence of business fake news. These scholars focus on the broader terms 'misinformation' and 'rumors,' not necessarily on fake news; yet, their concepts of 'comeback rumors,' rumor 'peaks,' 'persistent rumors,' 'external sources' of rumors, and rumor 'refreshing' may be transferrable and applicable to the business fake news setting. Future studies are welcome to explore, for instance, comeback or persistent fake news patterns related to personal hygiene products, food and beverage products, cosmetics, automobiles, and many more. There are opportunities here for both empirical (e.g., various geographical and temporal contexts) and theoretical business research (e.g., linguistic theories of persuasion, the Habermasian theory of communicative action, grounded theory).

The agenda-setting power of fake news and its agenda-setting predictions are tackled in Vargo et al. (2017) in a big data setting. This paper uses inter-media agenda-setting theory and the network agendasetting model. Although the study confirms that fake news websites' content is expanding, these websites "do not exert excessive power," the study finds (p. 2028). Online partisan media are found to be both responding to and setting the fake news' issue agenda. In a similar manner, upcoming business research may endeavor to find out what kinds of agenda business fake news sets, how powerful the fake news supporting websites are, and whom this power is directed at from an inter-media agenda-setting theory perspective.

Brigida and Pratt's (2017) work from the finance literature investigates how noise and well-informed trading are disseminated in the equity and options markets. They study the Twitter takeover hoax, which involved a tender offer hoax, and present a timeline of the fake news announcement with an accuracy to the minute. The fake news had a direct effect on Twitter's stock price. Future studies on the supply of 
fake news may continue this line of research based on other actual instances of company-related hoaxes, such as these targeting American Airlines, Rocky Mountain Chocolate, and Avon, all mentioned in the article. Fake news' effect on the stock price of publicly-traded companies and the timing of the counterrumor, if any, can also be the object of future scholarly projects.

To better understand the supply side of fake news, researchers need to investigate the how and the why of fake news' creation, transmission, and re-transmission, not. One promising avenue for further research builds on the levels of uncertainties' theoretical framework (Serra \& Sardar, 2017). This framework focuses on better understanding the relationship between the level of user uncertainty ('surface uncertainty,' 'shallow uncertainty,' and 'deep uncertainty,' as determined by the levels of contradictions, complexity, and chaos in a message) around an online message and the re-transmission of fake news on social media.

\section{Future Research on Demand}

Brummette et al. (2018) may be inspirational to those who aim to study the participation of the business community (e.g., executives, managers, accountants, entrepreneurs) in social media discussions on fake news. Among the possible questions to address are: What role does company affiliation play in these discussions? What role does entity type (e.g., not-for profit, corporate, partnership, proprietorship) play? What role does job title play? Adapting Bârgăoanu and Radu's (2018) research questions from the Romanian context in Table 1, scholars of business may concentrate on studying work-related groups, such as rank-and-file employees, management, or trustees. To better understand the demand side of fake news, it is necessary to investigate why people are drawn to, and believe in, fake news over real news stories. Nelson and Taneja (2017) highlight this issue from the lens of audience behavior theory, suggesting that distrust of real news is a bigger problem than the belief of fake news. More research that emulates this article's methodology is needed to better understand what makes fake business news believable and what business audiences' availability in the consumption of fake business news is.

Several studies not listed in Table 1 merit some attention. Future research on trust in fake news may determine whether there are co-relations between demographic characteristics and trust in fake business news settings. Such studies may expand on Warner-Søderholm et al.'s (2018) work on trust in social media by gender, age, and amount of time spent with social media. Warner-Søderholm and colleagues find that women and young users trust in social media more than other demographic groups. If this finding turns out to be also generalizable to fake business news, this fact will be likely to have some important implications on how to better protect susceptible young people from disinformation - e.g., food and health safety hoaxes (Wu, 2015).

Authentication of fake news on the demand side can also be further examined. Tandoc et al. (2018) present an 'act of authentication' model from the Singaporean context. The model is descriptive, rather than normative, and is centered on the internal/external evaluation of problematic sources. Internal authentication revolves around the 'source,' the 'message,' the 'self,' and 'popularity.' External authentication is qualified as 'incidental/intentional' and 'institutional/interpersonal.' Initial encounter with fake news may be followed by additional cross-checking with interpersonal or institutional sources (p. 10). Future studies in business may apply this framework to other contexts or contribute theoretically to the act of authentication of fake news model.

Another possible path for research is the Theory of Third-Person Perception (TPP). Jang and Kim (2018) study individuals' perceptions of media effects on themselves versus others. They find that people tend to think that others are more vulnerable to fake news than they are themselves. This theory builds on social identity theory that theorizes the relationship between the in-group and the out-group from a cognitive and affective perspective, among others. Future empirical studies may further Jang and Kim's take of TPP by studying other-than-US settings of partisan identity, social undesirability of content, and external political efficacy as predictors of the TPP. Attempts can also be made to contribute to the TPP theory based on new empirical findings that either corroborate, negate or better clarify the theory.

Following Baxter and Marcella (2017), qualitative researchers in business may use the observation method to find out employees,' consumers,' or suppliers' motivations for, and barriers to, the use of 
social media. Baxter and Marcella conduct over fifty interactive, electronically-assisted interviews to study the public's use of referendum campaign sites in the weeks just before the 2014 Scottish independence referendum. In upcoming research, participants may be observed and/or questioned as they perform their searches for information on sites that are known to host fake business news and disinformation. Results may be used to build further models of users' engagement.

One can also approach the empirical study of fake business news by studying consumers, just like Browning and Sweetser (2014) studied first-time voters' gratifications and their use of traditional news outlets compared with fake news outlets. Future studies on brands may further Berthon and Pitt's (2018) work on brands' place in truthiness and post-modernism: "Brands both fuel fake news and are burned by it" (p. 218). Another pathway for future research is in the realm of fake news comments related to products or services spread by online users (Morales, Sosa-Fey \& Farias, 2017). How should a company react to this kind of comments? Should it intervene immediately or not? Future studies may empirically test what approach is the ultimate one under the circumstances.

\section{CONCLUSION}

This paper reviewed the extant literature on fake news and provided guidance for future research on the topic of fake business news. It aimed to fill a considerable gap in the business literature - intentionally false business news that is made to resemble legitimate business news. Scholarly articles, such as Berthon and Pitt's (2018), Brigida and Pratt's (2017) and Wu's (2015) are among the first attempts in the business academic literature to confront the problem of fake news and other types of misinformation. A relatively recent phenomenon as it is, fake news is a very dangerous political, social, and economic issue. It has had a great influence on monumental decisions, such as presidential elections and referenda, as demonstrated in this paper. Fake news will continue to have an enormous impact on society and the business world should nothing or little is done to better understand and control its deceitful workings and mechanisms. Fake financial news can threaten the decision making of both individuals and businesses ("Fake financial news," 2017). Fake consumer-related news can mislead and disinform consumers with respect to their buying decisions; thus, consumers' impressions and perceptions of brands can be unfairly and adversely swayed by negative valence, a fact which can ultimately affect consumer loyalty and a company's ability to survive in the long run. Fake news does not only affect the micro-level, individual decision-making, but also the macro-level, structural one. The stock market, this flagship of the American economy, does not fail to quickly fall victim to fake news, too (Brigida \& Pratt, 2017). A better understanding of how and why fake news is created, transmitted, and re-transmitted on the supply side and consumed on the demand side remains necessary, so that this explosive phenomenon can be further controlled and hopefully put to rests very soon.

\section{ENDNOTES}

1. For more on the issue of fake news and democracy, see "Do Social Media" (2017) and "Fake News," (2017).

2. Attkisson (2017) states: "I wouldn't trust Snopes as an unbiased fact-checker...In the end...the general public should not be seeking a central arbiter of what is true or not." Quoting from John H. Johnson, she writes: "the most important issue is that consumers know to check things - who is authoring the story, what are the underlying affiliations, what are the sources, are they verifiable" (p. 272). 


\section{REFERENCES}

Akpinar, E., \& Berger, J. (2017). Valuable virality. Journal of Marketing Research, 54(2), 318-330. https://doi.org/10.1509/jmr.13.0350

Allcott, H., \& Gentzkow, M. (2017). Social media and fake news in the 2016 election. The Journal of Economic Perspectives, 31(2), 211-236. doi: 10.1257/jep.31.2.211

Amarasingham, A. (Ed.). (2011). The Stewart/Colbert effect: Essays on the real impacts of fake news. Jefferson, NC: McFarland.

An, J., Ciampaglia, G. L., Grinberg, N., Joseph, K., Mantzarlis, A., Maus, G., . . Welles, B. F. (2017). Reports of the workshops held at the 2017 international AAAI conference on web and social media. AI Magazine, 38(4), 93-98. Retrieved May 23, 2019, from https://aaai.org/ojs/index.php/aimagazine/article/view/2772

Anderson, K. E. (2017). Getting acquainted with social networks and apps: Social media in 2017. Library Hi Tech News, 34(10), 1-6. doi: 10.1108/LHTN-10-2017-0073

Aro, J. (2016). The Cyberspace war: Propaganda and trolling as warfare tools. European View, 15(1), 121-132. doi: 10.1007/s12290-016-0395-5

Attkisson, S. (2017). The smear: How shady political operatives and fake news control what you see, what you think, and how you vote. New York, NY: Harper-Collins.

Balmas, M. (2014). When fake news becomes real: Combined exposure to multiple news sources and political attitudes of inefficacy, alienation, and cynicism. Communication Research, 41(3), 430454. doi: $10.1177 / 0093650212453600$

Bârgăoanu, A., \& Radu, L. (2018). Fake news or disinformation 2.0? Some insights into Romanians' digital behaviour. Romanian Journal of European Affairs, 18(1), 24-38.

Bartlett, B. (2017). The truth matters: A citizen's guide to separating facts from lies and stopping fake news in its tracks. New York, NY: Ten Speed Press.

Bastos, M. T., \& Mercea, D. (2017). The Brexit Botnet and User-Generated Hyperpartisan News. Social Science Computer Review, 37(1), 38-54. doi: 10.1177/0894439317734157

Batchelor, O. (2017). Getting out the truth: The role of libraries in the fight against fake news. Reference Services Review, 45(2), 143-148. doi: 10.1108/RSR-03-2017-0006

Baxter, G., \& Marcella, R. (2017). Voters' online information behaviour and response to campaign content during the Scottish referendum on independence. International Journal of Information Management, 37(6), 539-546. doi: 10.1016/j.ijinfomgt.2017.05.013

Belhadjali, M., Whaley, G. L., \& Abbasi, S. M. (2017). Misinformation online: A preliminary review of survey results on Americans' perceptions by gender, ethnicity, and party affiliation. Competition Forum, 15(2), 324-328.

Bennett, W., \& Livingston, S. (2018). The disinformation order: Disruptive communication and the decline of democratic institutions. European Journal of Communication, 33(2), 122-139. doi: $10.1177 / 0267323118760317$

Berger, J., Sorensen, A. T., \& Rasmussen, S. J. (2010). Positive effects of negative publicity: When negative reviews increase sales. Marketing Science, 29(5), pp. 815-827. doi: $0.1287 / \mathrm{mksc} .1090 .0557$

Berthon, P. R., \& Pitt, L. F. (2018). Brands, truthiness and post-fact. Journal of Macromarketing, 38(2), 218-227. doi: $10.1177 / 0276146718755869$

Borah, A., \& Tellis, G. J. (2016). Halo (spillover) effects in social media: Do product recalls of one brand hurt or help rival brands? Journal of Marketing Research, 53(2), 143-160. doi: 10.1509/jmr.13.0009

Borden, S, \& Tew, C. (2007). The Role of journalist and the performance of journalism: Ethical lessons from "fake" news (seriously). Journal of Mass Media Ethics, 22(4), 300-314. doi: $10.1080 / 08900520701583586$

Brigida, M, \& Pratt, W. (2017). Fake news. North American Journal of Economics \& Finance, 42, 564573. doi: 10.1016/j.najef.2017.08.012 
Browning, N., \& Sweetser, K. D. (2014). The let down effect: Satisfaction, motivation, and credibility assessments of political infotainment. American Behavioral Scientist, 58(6), 810-826. doi: 10.1177/0002764213515227

Brummette, J., Marcia, D., Michail, V., \& Messner, M. (2018). Read all about it: The politicization of "fake news" on Twitter. Journalism \& Mass Communication Quarterly, 95(2), 497-517. doi: $10.1177 / 1077699018769906$

Burshtein, S. (2017). The true story on fake news. Intellectual Property Journal, 29(3), 397-446.

Chan, M. S., Jones, C. R., Jamieson, K. H., \& Albarracín, D. (2017). Debunking: A meta-analysis of the psychological efficacy of messages countering misinformation. Psychological Science. 28(11), pp. 1531-1546. doi: 10.1177/0956797617714579

Chua, A. Y. K. \& Banerjee, S. (2018). Intentions to trust and share online health rumors: An experiment with medical professionals. Computers in Human Behavior, 87, 1-9, doi: 0.1016/j.chb.2018.05.021

Chua, A. Y. K., Tee, C., Pang, A., \& Lim, E. (2017). The retransmission of rumor and rumor correction messages on Twitter. American Behavioral Scientist, 61(7), 707-723, doi: $10.1177 / 0002764217717561$

Ciampaglia, G. L., Mantzarlis, A., Maus, G., \& Menczer, F. (2018). Research challenges of digital misinformation: Toward a trustworthy web. AI Magazine, 39(1), 65-74.

Colicev, A., Kumar, A., \& O'Connor, P. (2018). Modeling the relationship between firm and user generated content and the stages of the marketing funnel. International Journal of Research in Marketing, 36(1), 100-116. doi: 10.1016/j.ijresmar.2018.09.005

Currie, S., (2018). Sharing posts: The spread of fake news. San Diego, CA: Reference Point.

Day, A. \& Thompson, E. (2012). Live from New York, It's the Fake News! Saturday Night Live and the (non)politics of parody. Popular Communication, 10(1-2), 170-182. doi: 10.1080/15405702.2012.638582 doi:10.1080/15405702.2012.638582

Dimitrova, D., \& Matthes, J. (2018). Social media in political campaigning around the world: Theoretical and methodological challenges. Journalism \& Mass Communication Quarterly, 95(2), 333-342. doi: $10.1177 / 1077699018770437$

Downes, C. (2018). Strategic blind-spots on cyber threats, vectors and campaigns. Cyber Defense Review, 3(1), 79-104. Retrieved May 23, 2019 from http://www.jstor.org/stable/26427378

Fake news: you ain't seen nothing yet. (2017a, July 1). The Economist. Retrieved from https://www.economist.com/science-and-technology/2017/07/01/fake-news-you-aint-seennothing-yet

Do social media threaten democracy? (2017b, November 4). The Economist. Retrieved from https://www.economist.com/leaders/2017/11/04/do-social-media-threaten-democracy

Fake news flourishes when partisan audiences crave it. (2018, April 5). The Economist. Retrieved from https://www.economist.com/finance-and-economics/2018/04/05/fake-news-flourishes-whenpartisan-audiences-crave-it

European Commission. (2018). A Multi-dimensional Approach to Disinformation. Report of the independent High level Group on fake news and online disinformation. Retrieved May 24, 2019, from https://ec.europa.eu/newsroom/dae/document.cfm?doc_id $=50271$.

Fernandez, P. (2017). The technology behind fake news. Library Hi Tech News, 34(7), 1-5. doi: 10.1108/LHTN-07-2017-0054

Ferrara, E., Varol, O., Davis, C., Menczer, F., \& Flammini, A. (2016). The rise of social bots. Communications of the ACM, 59(7), 96-104. doi: 10.1145/2818717

Fulgoni, G. M., \& Lipsman, A. (2017). The downside of digital word of mouth and the pursuit of media quality. Journal of Advertising Research, 57(2), 127-131. doi: 10.2501/JAR-2017-020.

Garrett, R. K., (2009). Echo chambers online? Politically motivated selective exposure among internet news users. Journal of Computer-Mediated Communication, 14(2), 265-285. doi: 10.1111/j.10836101.2009.01440.x 
Ghosh, D., \& Scott, B. (2018). Digital deceit: The technologies behind precision propaganda on the Internet. Retrieved May 23, 2019, from https://www.newamerica.org/public-interest-technology/policy-papers/digitaldeceit/

Gruen, T. W., Osmonbekov, T., \& Czaplewski, A. J. (2006). eWOM: The impact of customer-tocustomer online know-how exchange on customer value and loyalty. Journal of Business Research, 59(4), 449-456. doi: 10.1016/j.jbusres.2005.10.004

Hannan, J. (2018). Trolling ourselves to death? Social media and post-truth politics. European Journal of Communication, 33(2), 214-226. doi: 10.1177/0267323118760323

Hansen, N., Kupfer, A.-K., \& Hennig-Thuran, T. (2018). Brand crises in the digital age: The short- and long-term effects of social media firestorms on consumers and brands. International Journal of Research in Marketing, 35(4), 557-574. doi: 10.1016/j.ijresmar.2018.08.001

Harris, D., 2018. The fake news phenomenon. Minneapolis, MN: Core Library.

Hennig-Thurau, T., Gwinner, K. P., Walsh, G., \& Gremler, D. D. (2004). Electronic word-of-mouth via consumer-opinion platforms: What motivates consumers to articulate themselves on the Internet? Journal of Interactive Marketing, 18(1), 38-52. doi: 10.1002/dir.10073

Himelboim, I., Smith, M., \& Shneiderman, B. (2013). Tweeting apart: Applying networks analysis to explore selective exposure on Twitter. Communication Methods \& Measures, 7, 169-197.

Himelboim, I., Sweetser, K. D., Tinkham, S. F., Cameron, K., Danelo, M., \& West, K. (2016). Valencebased homophily on Twitter: Network analysis of emotions and political talk in the 2012 presidential election. New Media \& Society, 18(7), 1382-1140. doi: 10.1177/1461444814555096

Hsu, L. and Lawrence, B. (2016). The role of social media and brand equity during a product recall crisis: A shareholder value perspective. International Journal of Research in Marketing, 33, 59-77. doi: 10.1016/j.ijresmar.2015.04.004

Hynes, M. (2017). Shining a brighter light into the digital 'black box:' A call for stronger sociological (re)engagement with digital technology design, development and adoption debates. Irish Journal of Sociology, 26(1), 94-126. doi: 10.1177/0791603517741605

Jang, S. M., \& Kim, J. K. (2018). Third person effects of fake news: Fake news regulation and media literacy interventions. Computers in Human Behavior, 80, 295-302. doi: 10.1016/j.chb.2017.11.034

Jang, S. M., Tieming, G., Li, J.-Y. Q., Xia, R., Huang, C.-T., Kim, H., \& Tang, J. (2018). A computational approach for examining the roots and spreading patterns of fake news: Evolution tree analysis. Computers in Human Behavior, 84, 103-113. doi: 10.1016/j.chb.2018.02.032

Johnson, J. H., \& Gluck, M. (2016). Everydata: The misinformation hidden in the little data you consume every day why your gas tank isn't empty, you're not better than average, and Africa is bigger than you think. Brookline, MA: Bibliomotion.

Jones, R.H., \& Hafner, C.A. (2012). Understanding digital literacies. New York, NY: Routledge.

Fake financial news threatens Americans' decision-making abilities. (2017). Journal of Accountancy, 224(1), 9-15. Retrieved May 23, 2019, from

https://www.journalofaccountancy.com/issues/2017/jul/fake-financial-news.html

Jue, A. L., Marr, J. A., \& Kassotakis, M. E. (2010). Social media at work: How networking tools propel organizational performance. San Francisco, CA: Jossey-Bass.

Katz, E., \& Lazarsfeld, P. (1955). Personal influence: The part played by people in the flow of mass communications. Glencoe, IL: Free Press.

Klein, D., \& Wueller, J. (2017). Fake news: A legal perspective. Journal of Internet Law, 20(10), 1-13.

Krishna, A. (2017). Motivation with misinformation: Conceptualizing lacuna individuals and publics as knowledge-deficient, issue-negative activists. Journal of Public Relations Research, 29(4), 176193. doi: $10.1080 / 1062726 X .2017 .1363047$

Kshetri, N., \& Voas, J. (2017). The economics of "fake news." IT Professional Magazine, 19(6), 8-12. doi: 10.1109/MITP.2017.4241459 
Lance, B. W., \& Livingston, S. (2018). The disinformation order: Disruptive communication and the decline of democratic institutions. European Journal of Communication, 33(2), 122-139. doi: $10.1177 / 0267323118760317$

Lewandowsky, S., Ecker, U. K. H., \& Cook, J. (2017). Beyond misinformation: Understanding and coping with the "post-truth" era. Journal of Applied Research in Memory and Cognition, 6(4), 353-369. doi: 10.1016/j.jarmac.2017.07.008

Lewandowsky, S., Ecker, U. K. H., Seifert, C. M., Schwarz, N., \& Cook, J. (2012). Misinformation and its correction: Continued influence and successful debiasing. Psychological Science in the Public Interest, 13, 106-131. doi:10.1177/1529100612451018

Lor, P. J. (2018). Democracy, information, and libraries in a time of post-truth discourse. Library Management, 39(5), 307-321. doi: 10.1108/LM-06-2017-0061

Love, P. E. D. \& Ahiaga-Dagbui, D. D. (2018). Debunking fake news in a post-truth era: The plausible untruths of cost underestimation in transport infrastructure projects. Transportation Research Part A: Policy and Practice, 113, 357-368.

Mangold, W. G., \& Faulds, D. J. (2009). Social media: The new hybrid element of the promotion mix. Business Horizons, 52(4), 357-365. doi: 10.1016/j.bushor.2009.03.002

Mihailidis, P., \& Viotty, S. (2017). Spreadable spectacle in digital culture: Civic expression, fake news, and the role of media literacies in "post-fact" society. American Behavioral Scientist, 61(4), 441454. doi: $10.1177 / 0002764217701217$

Moe, W. W., \& Schweidel, D. A. (2012). Online product opinions: Incidence, evaluation, and evolution. Marketing Science, 31(3), 372-386. doi: 10.1287/mksc.1110.0662

Montgomery, L., \& Gray, B. (2017). Information veracity and the threat of fake news. In James M. Matarazzo \& T. Pearlstein (Eds.), The Emerald Handbook of Modern Information Management, (pp. 409-435). Bingley, United Kingdom: Emerald.

Morales, K., Sosa-Fey, J., \& Farias, J. (2017). Social media: Are the benefits worth the risks for business? International Journal of Business \& Public Administration, 14(1), 87-97.

Napoli, P. M. (2018). What if more speech is no longer the solution? First Amendment theory meets fake news and the filter bubble. Federal Communications Law Journal, 70(1), 55-104.

Nelson, J. L., \& Taneja, H. (2017). The small, disloyal fake news audience: The role of audience availability in fake news consumption. New Media \& Society, 20(10), 3720-3737. doi: $10.1177 / 1461444818758715$

Nematzadeh, A., Ciampaglia, G. L., Menczer, F., \& Flammini, A. (2017). How algorithmic popularity bias hinders or promotes quality. Ithaca, NY: Cornell University Library.

Nikolov, D., Oliveira, D. F. M., Flammini, A., \& Menczer, F. (2015). Measuring online social bubbles. Peer Journal of Computer Science, 1(38). doi: 10.7717/peerj-cs.38

Ortutay, B. (2018). YouTube aims to crack down on fake news, support journalism. Retrieved May 23, 2019, from: https://phys.org/news/2018-07-youtube-aims-fake-news-journalism.html

Poddar, A., Banerjee, S., \& Sridhar, K. (2019). False advertising or slander? Using location based tweets to assess online rating-reliability. Journal of Business Research, 99, 390-397. doi: 10.1016/j.jbusres.2017.08.030

Pariser, E. (2011). The filter bubble: What the Internet is hiding from you. London, United Kingdom: Penguin.

Pennycook, G. \& Rand, D. G. (2019). Lazy, not biased: Susceptibility to partisan fake news is better explained by lack of reasoning than by motivated reasoning. Cognition, 188, 39-50. doi: 10.1016/j.cognition.2018.06.011

Persily, N. (2017). Can democracy survive the internet? Journal of Democracy, 28(2), 63-76. doi: 10.1353/jod.2017.0025

Petrović, T. (2015). Serbia in the mirror: Parodying political and media discourses. Slavic Review, 74(2), 288-310. doi:10.5612/slavicreview.74.2.288

Prier, J. (2017). Commanding the trend: Social media as information warfare. Strategic Studies Quarterly, 11(4), 50-85. Retrieved from http://www.jstor.org/stable/26271634 
Relling, M., Schnittka, O., Sattler, H., \& Johnen, M. (2016). Each can help or hurt: Negative and positive word of mouth in social network brand communities. International Journal of Research in Marketing, 33, 42-58. doi: 10.1016/j.ijresmar.2015.11.001

Rochlin, N. (2017). Fake news: Belief in post-truth. Library Hi Tech, 35(3), 386-392. https://doi.org/10.1108/LHT-03-2017-0062

Rogers, E. (2003). Diffusion of innovations. New York, NY: Free Press.

Seargeant, P., \& Tagg, C. (2019). Social media and the future of open debate: A user-oriented approach to Facebook's filter bubble conundrum. Discourse, Context \& Media, 27, 41-48. doi: 10.1016/j.dcm.2018.03.005

Serra, J. \& Sardar, Z. (2017). Intelligence in postnormal times. World Futures Review, 9(3), 159-179. doi: $10.1177 / 1946756717709277$

Shin, J., Jian, L., Driscoll, K., \& Bar, F. (2018). The diffusion of misinformation on social media: Temporal pattern, message, and source. Computers in Human Behavior, 83, 278-287. doi: 10.1016/j.chb.2018.02.008

Spohr, D. (2017). Fake news and ideological polarization: Filter bubbles and selective exposure on social media. Business Information Review, 34(3), 150-160.

Spreadborough, D., \& Software, A. (2017). Exposing fraudulent digital images. Computer Fraud \& Security, 10, 11-13. doi: 10.1016/S1361-3723(17)30090-8

Stephen, A. T., \& Galak, J. (2012). The effects of traditional and social earned media on sales: A study of a microlending marketplace. Journal of Marketing Research. 49(5), 624-639. doi: 10.1509/jmr.09.0401

Tandoc, Jr., E. C., Ling, R., Westlund, O., Duffy, A., Goh, D., \& Wei, L. Z. (2018). Audiences' acts of authentication in the age of fake news: A conceptual framework. New Media \& Society, 20(8), 2745-2763. doi: 10.1177/1461444817731756

Tanner, R.J., \& Carlson, K.A. (2009). Unrealistically optimistic consumers: A selective hypothesis testing account for optimism in predictions of future behavior. Journal of Consumer Research, 35(5), 810-822. doi: $10.1086 / 593690$

Tesich, S. (1992). A government of lies. The Nation, 254 (1), 12-14.

Trusov, M., Bucklin, R. E., \& Pauwels, K. (2009). Effects of word-of-mouth versus traditional marketing: Findings from an Internet social networking site. Journal of Marketing, 73(5), 90-102. doi: 10.1509/jmkg.73.5.90

Tsipursky, G., \& Morford, Z. (2018). Addressing behaviors that lead to sharing fake news. Behavior and Social Issues, 27, AA6-AA10. doi:10.5210/bsi.v.27i0.8186

Vargo, C. J., Guo, L., \& Amazeen, M. A. (2017). The agenda-setting power of fake news: A big data analysis of the online media landscape from 2014 to 2016. New Media \& Society, 20(5), 20282049. doi: $10.1177 / 1461444817712086$

Wardle, C., \& Derakhshan, H. (2018). Information disorder: Toward an interdisciplinary framework for research and policy making, Council of Europe Report DGI (2017) 9. Retrieved May 23, 2019, from https://shorensteincenter.org/information-disorder-framework-for-research-andpolicymaking/

Warner-Søderholm, G., Bertsch, A., Sawe, E., Lee, D., Wolfe, T., Meyer, J., ... Fatilua, U. (2018). Who trusts social media. Computers in Human Behavior, 81, 303-315.doi: 10.1016/j.chb.2017.12.026

Wasserman, H. (2017). Fake news from Africa: Panics, politics and paradigms. Journalism. doi: $10.1177 / 1464884917746861$

Waszak, P. M., Kasprzycka-Waszak, W., \& Kubanek, A. (2018). The spread of medical fake news in social media - The pilot quantitative study. Health Policy \& Technology, 7(2), 115-118. doi: 10.1016/j.hlpt.2018.03.002

Weng, L., Flammini, A., Vespignani, A., \& Menczer, F. (2012). Competition among memes in a world with limited attention. Scientific Reports 2(335). doi: 10.1038/srep00335

$\mathrm{Wu}$, C.-W. (2015). Facebook users' intentions in risk communication and food-safety issues. Journal of Business Research, 68, 2242-2247. doi: 10.1016/j.jbusres.2015.06.005

Young, K. (2017). Bunk: The rise of hoaxes, humbug, plagiarists, phonies, post-facts, and fake news. Minneapolis, MN: Greywolf. 